\title{
Preservation of endangered Tunisian grapevine cultivars using embryogenic cultures
}

\author{
Badra Bouamama* \\ Centre de Biotechnologie de Borj-Cédria \\ Laboratoire de Physiologie Moléculaire de la Vigne. B.P. 901 \\ Hammam-lif, 2050, Tunisie \\ Tel: 0021679412938 \\ Fax: 0021679412638 \\ E-mail: Badra_bouamama@yahoo.com \\ Rahma Jardak \\ Centre de Biotechnologie de Borj-Cédria \\ Laboratoire de Physiologie Moléculaire de la Vigne. B.P. 901 \\ Hammam-lif, 2050, Tunisie \\ Tel: 0021679412938 \\ Fax: 0021679412638 \\ Asma Ben Salem \\ Centre de Biotechnologie de Borj-Cédria \\ Laboratoire de Physiologie Moléculaire de la Vigne. B.P. 901 \\ Hammam-lif, 2050, Tunisie \\ Tel: 0021679412938 \\ Fax: 0021679412638 \\ Abdelwahed Ghorbel \\ Centre de Biotechnologie de Borj-Cédria \\ Laboratoire de Physiologie Moléculaire de la Vigne. B.P. 901 \\ Hammam-lif, 2050, Tunisie \\ Tel: 0021679412938 \\ Fax: 0021679412638 \\ Ahmed Mliki \\ Centre de Biotechnologie de Borj-Cédria \\ Laboratoire de Physiologie Moléculaire de la Vigne. B.P. 901 \\ Hammam-lif, 2050, Tunisie \\ Tel: 0021679412938 \\ Fax: 0021679412638
}

Financial support: High Ministery of Education and Scientific Research and Technology.

Keywords: forced anthers, long-term maintenance, somatic embryos, Vitis vinifera.

Abbreviations: 2,4-D: 2,4-dichlorophenoxyacetic acid

CP: Chée and Pool (1987) basal medium

D: dichlorophenoxyacetic acid

IASP: indole 3 aspartic acid

MS: Murashige and Skoog

TDZ: thidiazuron

The preservation of embryogenic lines derived from several endangered local grapevine cultivars was studied. Embryogenic calluses were obtained from immature anthers of eight cultivars, sampled on both fruity-cuttings and field grown vines. Anthers at the 'separated flower' stage, derived from fruity-cuttings, resulted in an increased induction of somatic embryogenesis, compared to those derived from the field. Pro-embryogenic calluses were induced on Chée and Pool (1987) basal medium, supplemented with $9 \mu \mathrm{M}$ of 2,4-dichlorophenoxyacetic acid (2,4-D) and $11.35 \mu \mathrm{M}$ of thidiazuron (TDZ) under dark conditions. Different anther zones (filament, abaxial, adaxial, lateral zones and entire anthers) were involved in somatic embryogenesis induction. The percentages of granular and yellowish pro-embryogenic calluses ranged between

*Corresponding author 
$15.6 \%$ and $34.8 \%$ in 'Kahli Kerkennah' and 'Muscat Raf-raf' cultivars, respectively. Although, morphological diversifications of pro-embryogenic calluses (several necrosis and spontaneous maturation) were observed on the induction mediumafter 5 subcultures. The reduction of 2,4-D and TDZ levels to $4.52 \mu \mathrm{M}$ and $2.89 \mu \mathrm{M}$ respectively, induced granular and yellowish embryogenic material. Thus, Chée and Pool (1987) (CP) enriched with $4.52 \mu \mathrm{M}$ of 2,4-D and $2.89 \mu \mathrm{M}$ of TDZ revealed to be the most appropriate for long-term maintenance. In fact, all the cultivars presented high and regular embryo maturation rates after 12, 24, 36 and 48 months of cultivation on this medium, under light conditions. After 4 years, they still exhibit high germination and regeneration abilities. Germination of somatic embryos was achieved on Murashige and Skoog (1962) basal-medium, with rates ranging from $69 \%$ to $96 \%$. Only $5 \%$ of somatic embryos were concerned by morphological variations. The regenerated plantlets presented a normal phenotype under controlled greenhouse conditions, compared to mother plants.

Recent prospecting of local grapevine germplasm revealed that Tunisia possesses a rich patrimony which gathers around 35 distinct cultivars. These resources are very valuable as they present a distinct genetic pool in the Mediterranean basin (Zoghlami et al. 2003). Apart from the diversified organoleptic characteristics of their grapes (Souid et al. 2007), Tunisian cultivars seem to be well adapted to several biotic and abiotic constraints, regarding their wide geographical distribution all over the country. In fact, several were prospected in humid mountain areas, while others in arid peninsular zones (Kerkennah islands) and Saharan regions. Recent studies on the responses of several local cultivars to drought and salt stress (Ben Salem-Fnayou et al. 2006; Jellouli et al. 2008; Toumi et al. 2008) revealed their abilities to withstand a long-term water shortage ('Kahli', 'Turky' cultivars) and a high salt level ('Razzegui' cultivar). However, all local grapevine cultivars are seriously affected by viral diseases (fanleaf and leafroll) while several are currently facing extinction or genetic erosion (Jardak-Jamoussi et al. 2003; Zoghlami et al. 2003; Ben Salem-Fnayou et al. 2006). Despite the fact that most of the local grapevine cultivars are at present conserved as a unique field genebank, they always run the risk of destruction by natural calamities, pests and diseases (Kameswara-Rao, 2004). Thus, safety duplicates of endangered local grapevine cultivars, in particular, need to be established using biotechnological tools. In this respect, somatic embryogenesis could be an efficient tool for the preservation of Tunisian grapevine genetic resources, especially as embryogenic material could generate virusfree grapevine plants (Newton and Goussard, 1990). Therefore, maintaining a long-term embryogenic capacity has always been a target in genetic transformation programs (Kikkert et al. 2005).
To date, few studies have described the regeneration of local grapevine cultivars via somatic embryogenesis (Bouamama et al. 2007), but there have been no reports on the preservation of these cultivars via somatic embryogenesis. This research was carried out within the framework of the National Program for genetic resources preservation and exploiting; our goal being the preservation of several endangered local grapevine cultivars, through a long-term embryogenic culture establishment. Therefore, such embryogenic lines would particularly be valuable in bioprospecting (flavonoïds, stilbens (Kiselev et al. 2007), tannins).

In this study, the induction of somatic embryogenesis from anther explants, as well as the development of a long-term and reproducible system of somatic embryogenesis from several local grapevine cultivars is described.

\section{MATERIALS AND METHODS}

\section{Plant material and culture conditions}

Eight local cultivars (Vitis vinifera): 'Arich Ahmar', 'Arich Dressé', 'Asli’, 'Kahli Kerkennah', 'Kahli Sfax', 'Khamri Tozeur', 'Muscat Raf-raf' and 'Turky' were prospected all over the country in order to collect woody cuttings. Forcing was established under controlled conditions $\left(28^{\circ} \mathrm{C}\right.$ temperature, $90 \%$ relative humidity, 16 hrs photoperiod and $250 \mu \mathrm{mol} \mathrm{m} \mathrm{m}^{-2} \mathrm{~s}^{-1}$ light intensity), using three-node dormant
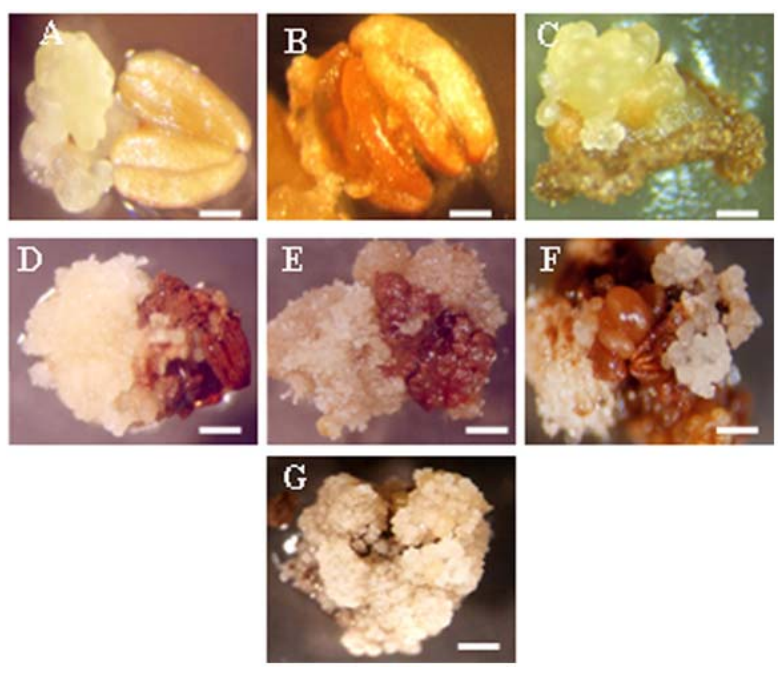

Figure 1. Embryogenic calluses derived from different anther zones:

(A) Primary callus on filament (Bar: $1 \mathrm{~mm})$.

(B) Primary callus on lateral zones (Bar: $1 \mathrm{~mm}$ ).

(C) Primary callus on abaxial and adaxial zones (Bar: $1 \mathrm{~mm}$ ).

(D) Pro-embryogenic callus derived from filament (Bar: 1 $\mathrm{mm})$.

(E) Pro-embryogenic callus derived from lateral zones (Bar: 1 $\mathrm{mm})$.

(F) Pro-embryogenic callus derived from abaxial and adaxial zones (Bar: $1 \mathrm{~mm}$ ).

(G) Pro-embryogenic callus derived from entire anther (Bar: 1 $\mathrm{mm})$. 


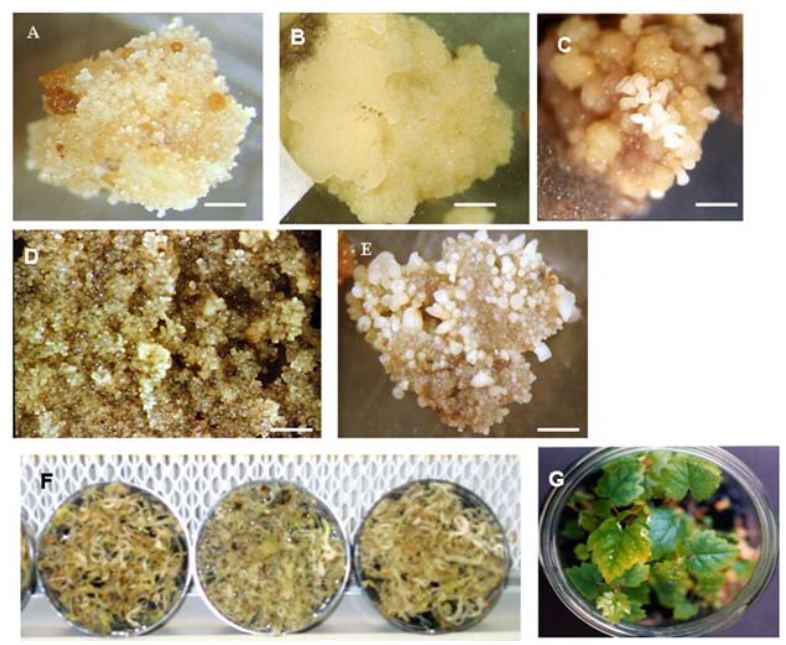

Figure 2. Embryogenic callus morphotypes and regeneration:

(A) Granular and yellowish pro-embryogenic callus cultivated on Chée and Pool (1987) supplemented with $9 \mu \mathrm{M}$ of 2,4-D and $11.35 \mu \mathrm{M}$ of TDZ under dark conditions (Bar: $1 \mathrm{~mm}$ ).

(B) Pro-embryogenic callus observed since the third subculture (pale-yellow colour) (Bar: $1 \mathrm{~mm}$ ).

(C) Spontaneous mature embryos observed after the fifth subculture (Bar: $1 \mathrm{~mm})$.

(D) Soft and necrotic tissues observed after the fifth subculture (Bar: $1 \mathrm{~mm}$ ).

(E) Asynchronous embryogenic callus, cultivated on Chée and Pool (1987) with $4.52 \mu \mathrm{M}$ of 2,4-D and $2.89 \mu \mathrm{M}$ of TDZ under 16 hrs photoperiod, exhibiting somatic embryos at different developmental stages (Bar: $1 \mathrm{~mm}$ ).

(F) Mass production of somatic embryos on Chée and Pool (1987) with $4.52 \mu \mathrm{M}$ of 2,4-D and $2.89 \mu \mathrm{M}$ of TDZ under $16 \mathrm{hrs}$ photoperiod.

(G) Regenerated plantlets on phytohormone-free MS medium.

cuttings as reported by Bouamama et al. (2007). Within 810 weeks, inflorescences were excised, disinfected in sodium hypochlorite $\left(6 \mathrm{gL}^{-1}\right)$ during $15 \mathrm{~min}$, and rinsed three times in sterile water containing citric acid $\left(0.03 \mathrm{gL}^{-1}\right)$ in the last bath.

\section{Induction of embryogenic calluses}

Immature anthers, excised from inflorescences derived from both fruity cuttings and field, were cultured on (Chée and Pool, 1987) basal medium (CP) supplemented with 9 $\mu \mathrm{M}$ of $2,4-\mathrm{D}, 11.35 \mu \mathrm{M}$ of TDZ and $3 \%$ sucrose. The medium ( $\mathrm{pH}$ 5.8) was solidified with $3 \%$ gelrite before autoclaving at $116^{\circ} \mathrm{C}$ for $24 \mathrm{~min}$ and distributed in $(60 \times 10$ $\mathrm{mm}$ ) Petri dishes ( $8 \mathrm{ml}$ per plate). Anthers were aseptically plated on their adaxial side in contact with the medium. Explants were incubated at $24 \pm 1^{\circ} \mathrm{C}$, under darkness. A total number of 25 explants per plate and five replicates from each cultivar were done. Induced calluses were subcultured on the same medium at 4 week- intervals, and three subcultures were finally done.

\section{Long-term maintenance medium for pro- embryogenic material}

The pro-embryogenic masses previously developed on the induction medium, were transferred to 3 culture media combinations, namely: CP supplemented with 1)- $4.52 \mu \mathrm{M}$ of 2,4-D; 2)- $2.89 \mu \mathrm{M}$ of TDZ 3)- $4.52 \mu \mathrm{M}$ of 2,4-D and $2.89 \mu \mathrm{M}$ of TDZ, respectively. Pro-embryogenic calluses (50 mg of fresh weight) from each cultivar were divided into 5 sections and incubated in $60 \mathrm{~mm}$ Petri dishes (containing $8 \mathrm{ml}$ of medium). Six Petri dishes per cultivar and combination were incubated under darkness and subcultured at 4 week-intervals, during 3 and 5 months.

\section{Maturation of somatic embryos}

In order to induce maturation, embryogenic calluses (50 mg in weight) from all the cultivars were transferred under 16 hrs photoperiod conditions $\left(57 \mu \mathrm{mol} \mathrm{m} \mathrm{m}^{-2} \mathrm{~s}^{-1}\right)$ on $\mathrm{CP}$ containing $4.52 \mu \mathrm{M}$ of 2,4-D and $2.89 \mu \mathrm{M}$ of TDZ.

Morphological observations were regularly done using light microscopy (Leica-).

\section{Plant regeneration}

To achieve germination, individual somatic embryos were transferred to Murashige and Skoog (1962) basal medium, containing $3 \%$ of sucrose and $0.3 \%$ of gelrite. Welldeveloped plantlets were transferred into peat pots and acclimatized under controlled greenhouse conditions $\left(24^{\circ} \mathrm{C}\right.$ temperature, $60 \%$ relative humidity, 16 hrs photoperiod).

\section{Statistical analysis}

All experiments were arranged in a randomized design. Data were analyzed using STATISTICA software. Comparisons were done using Duncan's multiple range tests.

\section{RESULTS}

\section{Induction and involvement of several anther zones in somatic embryogenesis}

Inflorescences were collected 20-25 days prior to anthesis at the 'separated flowers' stage ' $H$ ' (Baggiolini, 1952). At this stage, anthers were 0.5 to $0.8 \mathrm{~mm}$ in length; presented a green translucent colour and their microspores were at the tetrad stage (Bouamama et al. 2007). A comparison between anthers derived from fruity-cuttings and field revealed that forcing resulted in a significant decrease in the percentage of brown explants and increase in somatic embryogenesis induction (Table 1). Primary and proembryogenic calluses developed on the induction medium composed of CP basal medium containing $9 \mu \mathrm{M}$ of 2,4-D and $11.35 \mu \mathrm{M}$ of TDZ. Primary calluses were wellorganized, friable and yellowish and were found to 

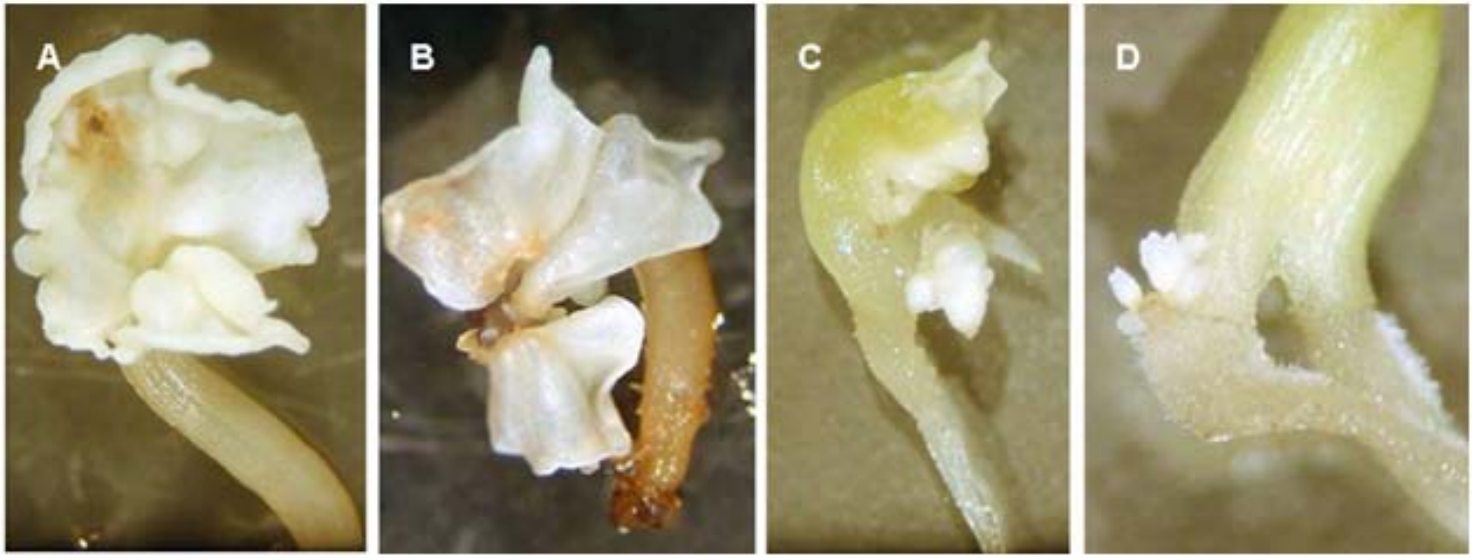

Figure 3. Teratological forms observed during the germinating period:

(A) Fused cotyledons.

(B) Pluri-cotyledonary forms, without any root system.

(C) Secondary embryos on the rudimentary cotyledons.

(D) Secondary somatic embryos on the root-hypocotyl ring.

originate from different anther zones (Figure 1). Regular microscopic observations of primary calluses showed that these structures developed after 4 weeks, but were still dependent on certain parental explant zones. Thus, primary calluses were located on the filament (Figure 1A), lateral zones (Figure 1B), adaxial and abaxial zones (Figure 1C) and rarely progressed on the entire anthers.

The pro-embryogenic masses were induced after 12-14 weeks of cultivation by three repeated subcultures of original calluses on fresh induction media. All the cultivars exhibited pro-embryogenic calluses on the filaments (Figure 1D), lateral zones, (Figure 1E), abaxial and adaxial zones (Figure $1 \mathrm{~F}$ ) as well as on the entire anthers (Figure $1 \mathrm{G})$. Independently from anther origin (fruity cuttings or field), the embryogenic induction was significantly dependent on the cultivar. In fact, the percentages of proembryogenic calluses ranged between $15.6 \%$ and $34.8 \%$ in 'Kahli Kerkennah' and 'Muscat Raf-raf' cultivars, respectively (Table 2).

\section{Long-term maintenance of pro-embryogenic cultures}

The pro-embryogenic masses, which were granular in texture and yellowish in colour (Figure 2A), were transferred to a refreshed induction medium (CP supplemented with $9 \mu \mathrm{M}$ of 2,4-D and $11.35 \mu \mathrm{M}$ of TDZ) for 5 further subcultures, in order to evaluate the growth and morphology of embryogenic calluses. Our results showed that the proliferation intensity of this material was not affected during the five subcultures; however, their colour turned to pale yellow since the third subculture (Figure 2B). After the fifth subculture, the calluses became diversified and generated several spontaneous mature embryos, as well as soft and necrotic tissues (Figure 2C, Figure 2D).
In order to conserve the yellowish and granular texture of the pro-embryogenic material, three media combinations, composed of CP enriched with 1) $4.52 \mu \mathrm{M}$ of $2,4-\mathrm{D}$; 2) $2.89 \mu \mathrm{M}$ of TDZ and 3) $4.52 \mu \mathrm{M}$ of 2,4-D and $2.89 \mu \mathrm{M}$ of TDZ were tested. After 9 subcultures, the combination of $4.52 \mu \mathrm{M}$ of $2,4-\mathrm{D}$ and $2.89 \mu \mathrm{M}$ of TDZ was found to be crucial for conservation of the morphology of proembryogenic lines as well as their proliferation intensity (Table 3). The results showed a significant increase in embryogenesis proliferation on this preservation medium for all the cultivars, compared to other combinations. As shown in Table 3, most of the embryogenic calluses reached their maturity on CP supplemented with TDZ (2.89 $\mu \mathrm{M})$, while they turned to brown and necrotic when cultured on CP enriched with $4.52 \mu \mathrm{M}$ of 2,4-D.

\section{Competency to maturation after a long-term maintenance period}

The homogenous, granular and yellowish pro-embryogenic calluses which were preserved under darkness, on CP supplemented with $4.52 \mu \mathrm{M}$ of $2,4-\mathrm{D}$ and $2.89 \mu \mathrm{M}$ of TDZ, were transferred to light conditions after 12, 24, 36 and 48 months of cultivation, in order to evaluate their competency to the maturation. Table 4 shows that maturation was not significantly affected by long-term maintaining of embryogenic material in 'Kahli Sfax', 'Muscat Raf-raf', 'Khamri' and 'Arich Ahmar'. However, a decreased competence was observed in 'Asli', 'Kahli Kerkennah' and 'Turky' cultivars. Therefore, the competence to the maturation varied from year to year in 'Arich Dressé' cultivar (Table 4). Within an additional 4 week-period, light microscopy observations allowed to distinguish globular, heart, torpedo and cotyledonary-shaped embryos (Figure 2E). 

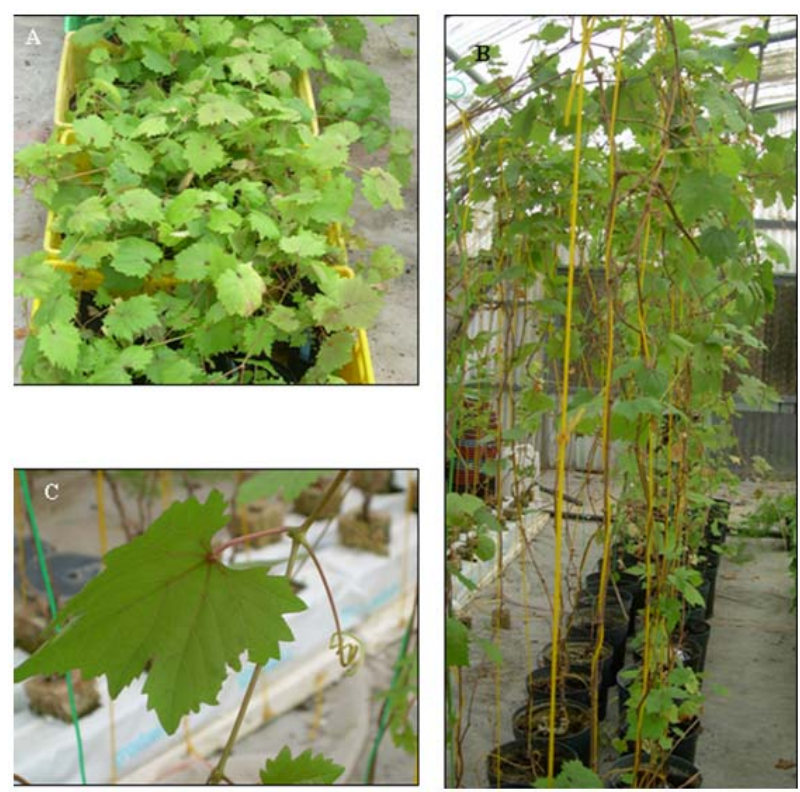

Figure 4. Plant regeneration:

(A) Plant acclimatization under controlled greenhouse conditions.

(B) Soiless cultivation of grapevine plants (peat).

(C) Classical ampelographic characteristics observed on adult grapevine plants (adult leaves, tendrils).

The mass production of mature cotyledonary-shaped embryos (Figure 2F) was achieved; these embryos successfully germinated into tiny plantlets on MS phytohormone-free medium (Figure 2G). During the germinating period, several teratological forms (5\%) were identified and varied from fused cotyledons (Figure 3A) to pluri-cotyledonary forms, without any root system (Figure 3B), secondary embryos on the rudimentary cotyledons (Figure 3C), and development of secondary somatic embryos on the root-hypocotyl connection zone (Figure 3D).

\section{Plant regeneration}

A high conversion rate of somatic embryos to plantlets was observed in all the cultivars (Table 5). Regenerated plantlets were acclimatized under controlled greenhouse conditions (Figure 4A). A high survival rate (90\% to 100\%) was recorded and plantlets exhibited a normal phenotype (ampelographic characteristics, phyllotaxy 1/2, tendrils) (Figure 4B, Figure 4C). Within the $3^{\text {rd }}$ year of cultivation, the first inflorescences appeared further to agricultural practices (pruning).

\section{DISCUSSION}

In this study, we were interested with the long-term preservation of pro-embryogenic lines from several endangered Tunisian grapevine cultivars (Vitis vinifera) and their whole plant regeneration. It is expected that the longterm preservation of pro-embryogenic lines would be further employed in genetic transformation programs of
Tunisian grapevines as well as in bio-prospecting. Based on this study, the source material as well as the interactive effect of phytohormones revealed to be the main factors controlling pro-embryogenic induction and preservation. In this report, a comparison between fruity-cutting (forced) and field (unforced) anther sources revealed that forcing significantly resulted in a decrease in anther necrosis and an increase in somatic embryogenesis percentages. In this context, Perrin et al. (2004) previously noticed that the embryogenic response is apparently influenced by the controlled conditions of fruity-cuttings. Furthermore, the cultivation of immature anthers (from both fruity-cuttings and field) at the 'separated flowers', 'stage H' (Baggiolini, 1952), as well as the use of (Chée and Pool, 1987) medium supplemented with 2,4-D $(9 \mu \mathrm{M})$ and TDZ $(11.35 \mu \mathrm{M})$ led to an efficient induction of somatic embryogenesis for all the cultivars. Generally, the induction of embryogenic structures from anthers is mostly based on combinations between 2,4-D and BAP (Gribaudo et al. 2004; Kikkert et al. 2005). However, BAP was successfully replaced by TDZ in several Vitis genotypes (Nakano et al. 1997; Bornhoff and Harst, 2000; Iocco et al. 2001). Although, TDZ effect highly depended on the grapevine in vitro regeneration system (embryogenesis initiation, secondary embryogenesis, microspore culture, long-term maintenance, protoplasts) as well as on the genotype. In fact, several Vitis rootstocks yielded embryogenic callus lines, on solid MS medium supplemented with 2,4-D and TDZ, which consequently regenerated entire plantlets (Olàh et al. 2003). Similarly, Nakajima and Matsuta (2003) showed that embryogenesis induction from leaf explants of Vitis vinifera cultivars was promoted by exogenous TDZ.

In this study, low levels of 2,4-D and TDZ were seemingly very crucial for the long-term maintenance of proembryogenic calluses in several local Vitis vinifera cultivars, without loss of their regenerative potential. Motoike et al. (2001) previously reported that a low level of TDZ was sufficient for long-term maintenance of embryogenic lines of Vitis x Labruscana cultivars.

On the other hand, regular morphologic observations confirmed the involvement of specific anther zones in embryogenesis induction (abaxial and adaxial zones, entire anthers, filament, lateral zones). Similar results were previously reported by Stamp and Meredith (1988) and Perrin et al. (2004); these authors proved that the filament and its detachment point were involved in the embryogenic induction. Therefore, Newton and Goussard (1990) reported that lateral anther zones induce somatic embryogenesis. However, the involvement of abaxial and adaxial zones as well as entire anthers in somatic embryogenesis induction was not reported so far.

Based on morphological characteristics, the well-organized friable and whitish primary calluses induced granular and yellowish pro-embryogenic masses on CP supplemented with $9 \mu \mathrm{M}$ of 2,4-D and 11.35 of TDZ within 12-14 weeks in all the cultivars. However, the induction medium, 
composed of (Chée and Pool, 1987) supplemented with 2,4$\mathrm{D}(9 \mu \mathrm{M})$ and TDZ $(11.35 \mu \mathrm{M})$, revealed to be unsuitable for conserving the appropriate pro-embryogenic morphology for more than 5 subcultures in all of the eight cultivars. Thus, the morphology of pro-embryogenic calluses became diversified, despite their weight gradation. Although, pro-embryogenic calluses could be maintained on the CP medium supplemented with $4.52 \mu \mathrm{M}$ of 2,4-D, and $2.89 \mu \mathrm{M}$ of TDZ, under dark conditions. This result suggests that the levels of 2,4-D and TDZ could be crucial for the proliferation and conservation of granular and yellowish pro-embryogenic calluses. Thus, the proliferation of these embryogenic lines lasted for more than 48 months without loss of their regenerative capacities. In this context, the embryogenic lines obtained by Motoike et al. (2001) from Vitis x labruscana have been stably maintained for more than two years. However, these authors completely prevented premature spontaneous embryogenesis and germination using low levels of 2,4-D and IASP (indole-3aspartic acid).

Similar results on the preservation of pro-embryogenic cultures from four seedless grapevine cultivars on MS supplemented with 2,4-D and IASP during 10 months reported, however, a spontaneous embryogenesis and premature germination (Perl et al. 1995). These authors inhibited these phenomena by adding ABA (abscissic acid) and maintained their embryogenic calluses for more than 18 months. Though, according to Kikkert et al. (2005), embryogenic cultures suitable for transformation were obtained from several Vitis genotypes, after more than one year, on Nitsch and Nitsch (1969) based-medium, supplemented with 2,4-D, NOA and TDZ.

The abnormalities which were observed after several subcultures in our long-term maintenance medium were also described by Motoike et al. (2001); the most common abnormality was the presence of more than two cotyledons or fused cotyledonary material.

To conclude, a protocol for a long-term maintenance of pro-embryogenic lines from several endangered Tunisian grapevines was established. This system would be efficient as an alternative strategy for grapevine genetic resources preservation and exploitation. Regarding the diversity of local cultivars, the long-term preserved embryogenic material would be particularly useful in bio-prospecting as well as in genetic transformation programs directed towards inducing tolerance to abiotic stresses.

\section{REFERENCES}

BAGGIOLINI, M. Les stades repères dans le développement annuel de la vigne et leur utilisation pratique. Revue Romande d'Agriculture de Viticulture et d'Arboriculture, 1952, vol. 8, p. 4-6.

BEN SALEM-FNAYOU, Asma; GUGERLI, Paul; ZEMNI, Hassène and GHORBEL, Abdelwahed. Decreased detectability of grapevine leafroll-associated virus 3 in Sakasly grapevines under the Sahara conditions. Journal of Phytopathology, May 2006, vol. 154, no. 9, p. 528-533.

BORNHOFF, B.A. and HARST, M. Establishment of embryo suspension cultures of grapevines (Vitis L.). Vitis, 2000, vol. 39, no. 1, p. 27-29.

BOUAMAMA, Badra; BEN SALEM-FNAYOU, Asma; MLIKI, Ahmed and GHORBEL, Abdelwahed. Production et entretien de 12 lignées embryogènes de variétés de vigne tunisiennes. Institut National de Normalisation et de la Propriété Industrielle, April 2007, vol. 18777, 9 p.

CHÉE, R and POOL, R.M. Improved inorganic media constituents for in vitro shoot multiplication of Vitis. Scientia Horticulturae, January 1987, vol. 32, no. 1-2, p. 85-95.

GRIBAUDO, Ivana; GAMBINO, Giorgio and VALLANIA, Rosalina. Somatic embryogenesis from grapevine anthers: The optimal developmental stage for collecting explants. American Journal of Oenology and Viticulture, April 2004, vol. 55, no. 4, p. 427-430.

IOCCO, P.; FRANKS, T. and THOMAS, M.R. Genetic transformation of major wine grape cultivars of Vitis vinifera L. Transgenic Research, 2001, vol. 10, no. 2, p. 105-112.

JARDAK-JAMOUSSI, Rahma; BOUAMAMA, Badra; WETZEL, Thierry; MLIKI, Ahmed; REUSTLE, Goetz M. and GHORBEL, Abdelwahed. Evaluation of different gene constructs for production of resistant grapevines against grapevine fanleaf and arabis mosaic viruses. Acta Horticulturae, 2003, vol. 603, p. 315-323.

JELLOULI, Neila; BEN JOUIRA, Hatem; SKOURI, Houda; GHORBEL, Abdelwahed; GARGOURI, Ali and MLIKI, Ahmed. Proteomic analysis of Tunisian grapevine cultivar Razegui under stress. Journal of Plant Physiology, March 2008, vol. 165, no. 5, p. 471-481.

KAMESWARA-RAO, N. Plant genetic resources: Advancing conservation and use through biotechnology. African Journal of Biotechnology, February 2004, vol. 3, no. 2, p. 136-145.

KISELEV, K.V.; DUBROVINA, A.S.; VUSLOVA, M.V.; BULGAKOV, V.P.; FEDOREYEV, S.A. and ZHURAVLEV, Y.N. The rolB gene-induced overproduction of resveratrol in Vitis amurensis transformed cells. Journal of Biotechnology, February 2007, vol. 128, no. 3, p. 681-692.

KIKKERT, Julie R.; STREIM, Michael J.; VIDAL, José R.; WALLACE, Patricia G.; BARNARD, John and REISCH, Bruce I. Long-term study of somatic embryogenesis from anthers and ovaries of 12 grapevine 
(Vitis sp.) genotypes. In vitro Cellular Developmental Biology-Plant, June 2005, vol. 41, no. 3, p. 232-239.

MOTOIKE, S.Y.; SKIRVIN, R.M.; NORTON, M.A. and OTTERBACHER, A.G. Somatic embryogenesis and long term maintenance of embryogenic lines from fox grape. Plant Cell Tissue Organ Culture, August 2001, vol. 66, no. 2, p. 121-131.

MURASHIGE, Toshio and SKOOG, Folke. A revised medium for rapid growth and bioassays with tobacco tissue cultures. Physiologia Plantarum, July 1962, vol. 15, no. 3, p. $472-497$.

NAKAJIMA, I and MATSUTA, N. Somatic embryogenesis from filaments of Vitis vinifera $\mathrm{L}$. and Vitis labruscana Bailey. Vitis, 2003, vol. 42, no. 1, p. 53-54.

NAKANO, M.; SAKIKABARA, T.; WATANABE, Y. and MU, M. Establishment of embryogenic cultures in several cultivars of Vitis vinifera and Vitis x labruscana. Vitis, 1997, vol. 36, p. 141-145.

NEWTON, D.J. and GOUSSARD, P.G. The ontogeny of somatic embryos from in vitro cultured grapevine anthers. South Africa Journal of Enology and Viticulture, June 1990, vol. 11, no. 2, p. 70-75.

NITSCH, J.P. and NITSCH, C. Haploid plants from pollen grains. Science, 1969, vol. 163, no. 3862, p. 85-87.

OLÀH, R.; SZEGEDI, E.; RUTHNER, S. and KORBULY, J. Thidiazuron-induced regeneration and genetic transformation of grapevine rootstock varieties. Vitis, 2003, vol. 42, no. 3, p. 133-136.

PERL, Avihai; SAAD, Shoshana; SAHAR, Nachman and HOLLAND, Doron. Establishment of long-term embryogenesis cultures of seedless Vitis vinifera cultivars-a synergistic effect of auxins and the role of abscisic acid. Plant Science, October 1995, vol. 104, no. 2, p. 193-200.

PERRIN, Mireille; GERTZ, Claude and MASSON, Jean E. High efficiency initiation of regenerable embryogenic callus from anther filaments of 19-grapevine genotypes grown worldwide. Plant Science, August 2004, vol. 167, no. 6, p. 1343-1349.

STAMP, James A. and MEREDITH, Carole P. Proliferative somatic embryogenesis from zygotic embryos of grapevine. Journal of the American Society for Horticultural Science, 1988, vol. 113, p. 941-945.

SOUID, I.; Zemni, H.; SANCHEZ-PALOMO, E.; PEREZCOELLO, M.S. and GHORBEL, A. Varietal aroma compound of Vitis vinifera cv. Khamri grown in Tunisia. Journal of Food Quality, 2007, vol. 30, no. 5, p. 718-730.

TOUMI, I.; GARGOURI, M.; NOUAIRI, I.; MOSCHOU, P.N.; BEN SALEM-FNAYOU, A.; MLIKI, A.;
ZARROUK, M. and GHORBEL, A. Water stress induced changes in the leaf lipid composition of four grapevine genotypes with different drought tolerance. Biologia Plantarum, 2008, vol. 52, no. 1, p. 161-164.

ZOGHLAMI, N.; ROUX, C.; LAUCOU, V.; LAUCOMBE, T.; MLIKI, A.; THIS, P. and GHORBEL, A. Genetic specificity of Tunisian grapevines as assessed by SSR markers. In: Proceedings de la $83^{\text {ème }}$ Assemblée Générale de l'Office International de la Vigne (O.I.V.). June 2003, p. 16-19. 


\section{APPENDIX \\ TABLES}

Table 1. Effect of anther origin (field and fruity cuttings) on the embryogenic induction on Chée and Pool (1987) supplemented with $9 \mu \mathrm{M}$ of 2,4-D and $11.35 \mu \mathrm{M}$ of TDZ, independently from cultivars.

\begin{tabular}{|c|c|c|}
\hline & Unforced (field) & Forced (fruity cuttings) \\
\hline Anther necrosis & $35.6 \pm 6.9 \mathrm{a}$ & $14.8 \pm 2.1 \mathrm{~b}$ \\
\hline \hline Embryogenesis & $17.2 \pm 3.7 \mathrm{~b}$ & $28.7 \pm 8.0 \mathrm{a}$ \\
\hline
\end{tabular}

In each row, means followed by different letters are significantly different at $\mathrm{P}<0.05$ according to Duncan's multiple range tests.

Table 2. Effect of the cultivars on somatic embryogenesis induction on Chée and Pool (1987) supplemented with $9 \mu \mathrm{M}$ of 2,4-D and $11.35 \mu \mathrm{M}$ of TDZ, independently from anther origin.

\begin{tabular}{|c|c|}
\hline Cultivars & $\begin{array}{c}\text { Embryogenesis } \\
\text { induction }\end{array}$ \\
\hline 'Arich Ahmar' & $19.2 \pm 2.9 \mathrm{bc}$ \\
\hline 'Arich Dressé' & $23.6 \pm 3.2 \mathrm{bc}$ \\
\hline 'Asli' & $18.0 \pm 2.2 \mathrm{bc}$ \\
\hline 'Kahli Kerkennah' & $15.6 \pm 1.1 \mathrm{c}$ \\
\hline 'Kahli Sfax' & $16.8 \pm 1.7 \mathrm{bc}$ \\
\hline 'Khamri Tozeur' & $24 \pm 3.7 \mathrm{~b}$ \\
\hline 'Muscat Raf-raf' & $34.8 \pm 7.2 \mathrm{a}$ \\
\hline 'Turky' & $31.6 \pm 4.7 \mathrm{a}$ \\
\hline
\end{tabular}

Means followed by different letters are significantly different at $\mathrm{P}<0.05$ according to Duncan's multiple range tests. 
Table 3. Percentages of pro-embryogenic calluses observed after nine subcultures on Chée and Pool (1987) supplemented with 1) $4.52 \mu \mathrm{M}$ of 2,4-D; 2) $2.89 \mu \mathrm{M}$ TDZ and 3) $4.52 \mu \mathrm{M}$ of 2,4-D and $2.89 \mu \mathrm{M}$ TDZ.

\begin{tabular}{|c|c|c|}
\hline Cultivars & $\begin{array}{l}\text { Phytohormones } \\
\text { combinations }\end{array}$ & $\begin{array}{l}\% \text { of pro-embryogenic } \\
\text { calluses after nine subcultures }\end{array}$ \\
\hline 'Muscat Raf-raf' & $\begin{array}{c}2,4-\mathrm{D} \\
\text { TDZ } \\
2,4-\mathrm{D}+\mathrm{TDZ}\end{array}$ & $\begin{array}{c}30 \pm 4.13 \mathrm{~b} \\
56.6 \pm 7.79 \mathrm{a} \\
76.6 \pm 4.9 \mathrm{a}\end{array}$ \\
\hline ‘Kahli Kerkennah' & $\begin{array}{c}2,4-\mathrm{D} \\
\text { TDZ } \\
2,4-\mathrm{D}+\mathrm{TDZ}\end{array}$ & $\begin{array}{l}13.3 \pm 2.2 b \\
83.3 \pm 8.8 \mathrm{a} \\
96.6 \pm 8.1 \mathrm{a}\end{array}$ \\
\hline 'Asli' & $\begin{array}{c}2,4-\mathrm{D} \\
\text { TDZ } \\
2,4-\mathrm{D}+\mathrm{TDZ}\end{array}$ & $\begin{array}{c}6.6 \pm 1.25 \mathrm{~b} \\
57 \pm 8.1 \mathrm{a} \\
76 \pm 6.8 \mathrm{a}\end{array}$ \\
\hline 'Arich Dressé' & $\begin{array}{c}2,4-\mathrm{D} \\
\text { TDZ } \\
2,4-\mathrm{D}+\mathrm{TDZ}\end{array}$ & $\begin{array}{c}23.3 \pm 3.1 b \\
36.6 \pm 8.98 b \\
63.3 \pm 4 a\end{array}$ \\
\hline 'Arich Ahmar' & $\begin{array}{c}2,4-\mathrm{D} \\
\text { TDZ } \\
2,4-\mathrm{D}+\mathrm{TDZ}\end{array}$ & $\begin{array}{c}13.3 \pm 2.2 b \\
20 \pm 7.0 b \\
53.3 \pm 5.9 a\end{array}$ \\
\hline 'Kahli Sfax' & $\begin{array}{c}2,4-\mathrm{D} \\
\text { TDZ } \\
2,4-\mathrm{D}+\mathrm{TDZ}\end{array}$ & $\begin{array}{c}23.3 \pm 3.74 \mathrm{c} \\
43.3 \pm 5.57 \mathrm{~b} \\
100 \pm 4.9 \mathrm{a}\end{array}$ \\
\hline 'Turky’ & $\begin{array}{c}2,4-\mathrm{D} \\
\text { TDZ } \\
2,4-\mathrm{D}+\mathrm{TDZ}\end{array}$ & $\begin{array}{c}26.6 \pm 5.13 b \\
46.6 \pm 9.4 b \\
90 \pm 3.1 a\end{array}$ \\
\hline ‘Khamri Tozeur’ & $\begin{array}{c}2,4-\mathrm{D} \\
\text { TDZ } \\
2,4-\mathrm{D}+\mathrm{TDZ}\end{array}$ & $\begin{array}{r}24 \pm 3.13 b \\
49 \pm 9.4 b \\
90 \pm 5.2 a\end{array}$ \\
\hline
\end{tabular}

For each cultivar, means followed by different letters are significantly different at $\mathrm{P}<0.05$ according to Duncan's multiple range tests. 
Table 4. Mean number of mature somatic embryos derived from long-term maintained calluses within $12,24,36$ and 48 months.

\begin{tabular}{|c|c|c|c|c|}
\hline \multirow{2}{*}{ Cultivars } & \multicolumn{4}{|c|}{$\begin{array}{c}\text { Mean number of mature somatic embryos } \\
\text { within a proliferation period of }\end{array}$} \\
\cline { 2 - 5 } & 12 months & 24 months & 36 months & 48 months \\
\hline 'Asli' (*) & $234.33 \pm 11.26 \mathrm{~b}$ & $245.33 \pm 12.77 \mathrm{~b}$ & $282 \pm 32.6 \mathrm{a}$ & $192 \pm 14.11 \mathrm{c}$ \\
\hline 'Kahli Kerkennah' (*) & $318.17 \pm 12.92 \mathrm{a}$ & $329.66 \pm 17.77 \mathrm{a}$ & $263.67 \pm 26.01 \mathrm{~b}$ & $230.83 \pm 19.02 \mathrm{c}$ \\
\hline 'Muscat Raf-raf' (NS) & $220.33 \pm 7.15$ & $208.33 \pm 14.18$ & $209.33 \pm 12.14$ & $211.66 \pm 3.37$ \\
\hline 'Arich Dressé'(*) & $218.5 \pm 11.33 \mathrm{~b}$ & $248.16 \pm 14.49 \mathrm{a}$ & $189.5 \pm 12 \mathrm{c}$ & $240.66 \pm 12.3 \mathrm{a}$ \\
\hline 'Turky' (*) & $260.5 \pm 11.58 \mathrm{a}$ & $239.16 \pm 17.97 \mathrm{~b}$ & $265.0 \pm 11.51 \mathrm{a}$ & $211.5 \pm 7.49 \mathrm{c}$ \\
\hline 'Kahli Sfax'(NS) & $232.83 \pm 7.4$ & $243.5 \pm 4.98$ & $241.33 \pm 5.57$ & $245.83 \pm 12.81$ \\
\hline 'Khamri Tozeur'(NS) & $253.83 \pm 10.5$ & $265.5 \pm 8$ & $272.16 \pm 9.73$ & $267.5 \pm 8.99$ \\
\hline 'Arich Ahmar'(NS) & $242.7 \pm 10.3$ & $252.7 \pm 6.3$ & $266.7 \pm 10.5$ & $260.1 \pm 11.6$ \\
\hline
\end{tabular}

Somatic embryos were counted on embryogenic masses (50 mg fresh weight), in each cultivar.

The values are the means of 6 replicates per cultivar.

For each cultivar, means followed by different letters are significantly different at $\mathrm{P}<0.05$ according to Duncan's multiple range tests.

Abbreviations: NS: Not Significant; *: Significant.

Table 5. Mean regeneration rates of plantlets derived from the germination of somatic embryos on full strength Murashige and Skoog (1962).

\begin{tabular}{|c|c|}
\hline Cultivars & Regeneration rates (\%) \\
\hline Asli & $68.9 \pm 4.62 \mathrm{~b}$ \\
\hline Muscat Raf-raf & $95.6 \pm 2.06 \mathrm{a}$ \\
\hline Arich Ahmar & $70.2 \pm 4.57 \mathrm{~b}$ \\
\hline Arich Dressé & $90.9 \pm 2.88 \mathrm{a}$ \\
\hline Turky & $90 \pm 3 \mathrm{a}$ \\
\hline Kahli Kerkennah & $92.5 \pm 2.63 \mathrm{a}$ \\
\hline Kahli Sfax & $78.8 \pm 4.11 \mathrm{ab}$ \\
\hline Khamri Tozeur & $92.5 \pm 2.63 \mathrm{a}$ \\
\hline
\end{tabular}

Means followed by different letters are significantly different at $\mathrm{P}<0.05$ according to Duncan's multiple range tests. 